Jurnal Ilmu Keperawatan Medikal Bedah Vol. 3 (2), Bulan November Tahun 2020 , Hal. 23-31 ISSN 2338-2058 (print), ISSN 2621-2986 (online)

\title{
Diabetes Self Management dan Faktor yang Mempengaruhinya pada Usia Dewasa Pertengahan
}

\author{
Sucipto Dwitanta1, Debie Dahlia² \\ ${ }^{1}$ Mahasiswa Program Studi Magister Ilmu Keperawatan, Fakultas Ilmu Keperawatan, \\ Universitas Indonesia \\ ${ }^{2}$ Dosen Keperawatan Medikal Bedah, Fakultas Ilmu Keperawatan, Universitas Indonesia \\ Corresponding author: suciptodwi0090@gmail.com
}

\begin{abstract}
Diabetes mellitus is six main causes of death in the world. Diabetes mellitus that is not managed properly can run the risk of causing various long-term complications. Type 2 diabetes has a prevalence of 2 to 2.5 times more risk of heart disease accompanied by microvascular and macrovascular complications. Prevent various kinds of life-threatening complications in middle adulthood is to use the diabetes self management (DSM) approach. DSM desperately needs commitment to a very complex diabetes management regimen to achieve good glycemic control. This literature review aims to analyze factors affecting diabetes self management in type 2 diabetes in middle-age adult patients. The literature review used in this study uses journal related by searching in scientific-based databases, with keywords used middle-age adult - diabetes self-management - type 2 diabetes. Based on the literature results, several factors that can affect DSM in middle-aged adult patients include depression, self-efficacy, social support, and knowledge. Therefore, the importance of further research is to be able to see which factors are the most influential among the four factors, so that nurses can make plans to overcome these problems.
\end{abstract}

Keywords: diabetes mellitus, diabetes self management, middle-age adult

\section{PENDAHULUAN}

Diabetes adalah penyakit pada gangguan gangguan metabolik kronik yang didapat apabila pankreas tidak mampu memproduksi insulin (hormon yang mengatur kadar gula dalam darah) yang cukup atau ketika tubuh tidak dapat secara efektif menggunakan insulin yang diproduksinya (WHO, 2016; Widodo, 2014). Diabetes dapat dikelompokan menjadi tipe 1, tipe 2 dan diabetes getasional (Alhaik, Anshasi, Alkhawaldeh, Soh, \& Naji, 2019). Diabetes tipe 2 merupakan diabetes dengan tingkat prevalensi yang cukup tinggi (IDF, 2019).

Harapan hidup merupakan indikator penting dari kondisi kesehatan dan perkembangan sosial suatu negara di antara faktor-faktor lain (Ncube, 2019). Dengan demikian peningkatan kondisi kesehatan dan perkembangan sosial ekonomi dapat menggambarkan bahwa terjadi peningkatan harapan hidup yang mengakibatkan individu dapat hidup lebih lama dari yang diharapkan. Semakin tinggi angka morbiditas, semakin banyak pula penurunan harapan hidup.

Dwitanta, S., \& Dahlia, D.,_Diabetes Self Management dan Faktor yang Mempengaruhinya... 23 
Jurnal Ilmu Keperawatan Medikal Bedah Vol. 3 (2), Bulan November Tahun 2020 , Hal. 23-31 ISSN 2338-2058 (print), ISSN 2621-2986 (online)

Pada tahun 2019 DM termasuk dalam enam penyebab utama dari kematian. Hasil penelitian yang dilakukan oleh (Ncube, 2019) melaporkan bahwa pasien DM tipe 2 mempunyai prevalensi 2 sampai 2,5 kali lebih berisiko terkena CVD (cardiovascular disease). Penelitian Arambewela et al. (2018) juga menjelaskan hasil studi yang dilakukan pada 3000 pasien dengan diabetes melitus tipe 2 dengan tingkat prevalensi komplikasi makrovaskular pada penyakit jantung $(10,6 \%)$, stroke $(1,1 \%)$ dan penyakti pembuluh darah perifer $(4,7 \%)$, sedangkan komplikasi makrovaskular retinopati $(26,1 \%)$, neuropati $(62,6 \%)$, nefropati $(50,8 \%)$, kaki diabetik (2,6\%), dan amputasi pada ekstremitas bawah $(1,3 \%)$.

Indonesia menempati urutan peringkat ke tujuh di dunia untuk prevalensi penderita diabetes melitus tertinggi di dunia pada tahun 2019, bersamaan dengan beberapa negara seperti China, India, Amerika Serikat, Brazil, Rusia dan Meksiko (IDF, 2019). Hasil riset kesehatan dasar (Riskesdas) tahun (2018) menunjukan bahwa secara nasional, prevalensi diabetes melitus di Indonesia sebesar 1,5\%. Prevalensi nasional diabetes cenderung lebih tinggi pada masyarakat dengan usia antara 55-64 tahun (6,29\%).

Diabetes melitus yang tidak dimanajemen secara tepat dan benar, maka dapat berisiko mengakibatkan bermacam-macam komplikasi jangka panjang. Kadar glukosa dalam darah yang tinggi secara konsisten dapat mengakibatkan penyakit serius yang dapat mempengaruhi semua sistem (Kirk et al., 2015). Pasien dewasa pertengahan dengan diabetes memiliki risiko lebih tinggi terjadinya komplikasi dan memungkinkan untuk mengalami kondisi komorbiditas (CKD, retinopati dan neuropati) dan risiko perburukan kondisi penyakit (seperti kerusakan organ tahap akhir) yang sangat berhubungan dengan memburuknya kontrol gula darah dan dapat mengganggu perilaku perawatan diri (self care) serta memberikan dampak besar pada status kesehatan (Beverly, Ritholz, Shepherd, \& Weinger, 2016; Li et al., 2017; Weinger, Beverly, \& Smaldone, 2014).

Penelitian yang dilakukan oleh Romakin and Mohammadnezhad (2019) menjelaskan bahwa ada beberapa faktor yang dapat memicu terjadinya kontrol glikemik yang buruk yaitu kepatuhan pasien yang buruk terhadap rencana perawatan dan manajemen yang sudah ditentukan, sikap buruk pasien (seperti kurangnya motivasi untuk menjaga kesehatan mereka sendiri, dengan terlalu banyak ketergantungan pada penyedia layanan kesehatan), kurang atau terbatasnya pengetahuan pasien (khususnya tentang diabetes, komplikasi dan tujuan pengobatannya), adanya pengaruh budaya dan kepercayaan pasien tentang pengobatan tradisional diabetes serta kurangnya dukungan keluarga.

Cara untuk mencegah berbagai macam komplikasi yang dapat mengancam jiwa pada dewasa pertengahan adalah menggunakan pendekatan Diabetes Self Management (DSM). DSM merupakan hal yang menantang dan sangat membutuhkan kepatuhan dan komitmen terhadap rejimen pengelolaan diabetes yang sangat kompleks untuk mencapai kontrol glikemik yang baik. Pengontrolan penyakit DM dapat dimulai dengan melakukan manajemen gula darah, kontrol diit, aktivitas fisik dan penggunaan perawatan kesehatan (Wu, Tai, \& Sun, 2019).

Dwitanta, S., \& Dahlia, D.,_Diabetes Self Management dan Faktor yang Mempengaruhinya... 24 
Jurnal Ilmu Keperawatan Medikal Bedah Vol. 3 (2), Bulan November Tahun 2020 , Hal. 23-31 ISSN 2338-2058 (print), ISSN 2621-2986 (online)

Tinjauan literatur ini bertujuan untuk mencari tau dan menganalisa tentang faktorfaktor apa saja yang dapat mempengaruhi diabetes self management pada diabetes tipe 2 usia dewasa pertengahan.

\section{METODE}

Metode yang digunakan pada artikel ini menggunakan pendekatan tinjauan literatur. Artikel yang dikumpulkan akan dipilih berdasarkan kriteria pencarian: a) artikel berbahasa inggris, b) publikasi antara tahun 2010 - 2020, c) tersedianya teks lengkap, dan d) artikel penelitian kuantitatif maupun kualitatif. Artikel yang sudah memenuhi kriteria inklusi akan dilakukan analisa pada hasil penelitian. Sumber pada artikel ini menggunakan data base berbasis ilmiah (ScienceDirect, PubMed, EBSCOhost, dan Wiley Library Online). Pencarian akan dimulai diantara bulan Januari 2020 - Februari 2020 yang menggunakan kata kunci middle-age adult - diabetes self management - diabetes tipe 2 - factor affecting. Pencarian artikel menitik beratkan pada faktor-faktor apa saja yang dapat mempengaruhi diabetes self management pada pasien dewasa pertengahan.

\section{HASIL}

Hasil pencarian dalam database didapatkan 76 artikel. Kemudian peneliti melakukan penyaringan pada judul dan isi artikel penelitian dengan menggunakan instrumen Strengthening the reporting of observational studies in Epidemiology (STROBE Statement) yang dilakukan oleh peneliti sendiri dan satu orang asisten penelitian yang membantu dalam menyaring artikel. Tujuan penyaringan artikel yang diperoleh untuk melakukan pemilihan terhadap tema yang mirip atau sama serta artikel yang tidak relevan dengan tujuan penelitian ini. Hanya beberapa artikel yang sesuai dengan tujuan penelitian ini. Hasil didapatkan 8 artikel yang akan dilakukan proses analisa.

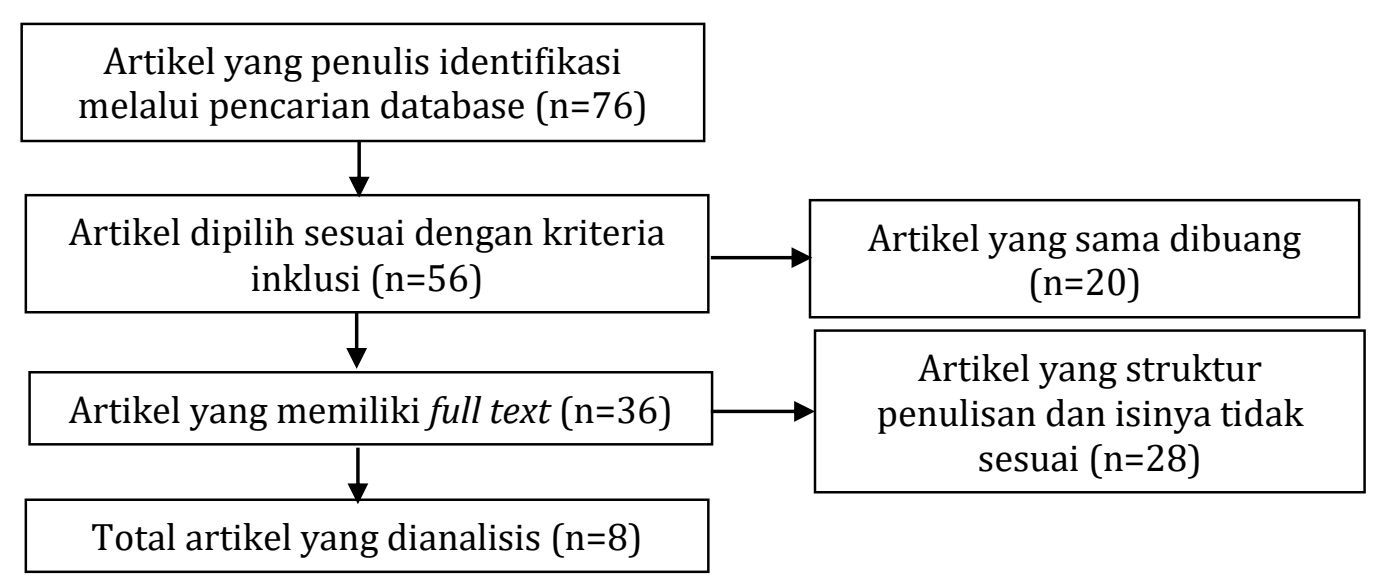

Gambar 1. Bagan Alur Review Artikel yang dianalisis

Dwitanta, S., \& Dahlia, D.,_Diabetes Self Management dan Faktor yang Mempengaruhinya... 25 
Jurnal Ilmu Keperawatan Medikal Bedah Vol. 3 (2), Bulan November Tahun 2020 , Hal. 23-31

ISSN 2338-2058 (print), ISSN 2621-2986 (online)

Tabel 1

Tabel Ringkasan Artikel

\begin{tabular}{|c|c|c|c|c|c|}
\hline Judul & Tahun & Penulis & Metode & Sampel & Hasil \\
\hline $\begin{array}{l}\text { When knowing is not } \\
\text { enough: Emotional } \\
\text { Distress and depression } \\
\text { reduce the positive effects } \\
\text { of health literacy on } \\
\text { diabetes self management }\end{array}$ & 2018 & $\begin{array}{l}\text { Louise } \\
\text { Schinckus, } \\
\text { Florence } \\
\text { Dangoisse, } \\
\text { Stephan } \\
\text { Vanden } \\
\text { Broucke, Moïra } \\
\text { Mikolajczak }\end{array}$ & $\begin{array}{l}\text { Cross- } \\
\text { sectional }\end{array}$ & $\begin{array}{l}\text { Usia } \\
\text { dewasa } \\
(\geq 18 \\
\text { tahun })\end{array}$ & $\begin{array}{l}\text { Gangguan emosional, baik yang } \\
\text { berhubungan dengan diabetes atau } \\
\text { tidak, dapat menghalangi pasien } \\
\text { untuk melakukan kegiatan perilaku } \\
\text { diabetes self management yang } \\
\text { memadai. }\end{array}$ \\
\hline
\end{tabular}

\begin{tabular}{|c|c|c|c|c|c|}
\hline $\begin{array}{l}\text { Effects of depression, } \\
\text { diabetes distress, diabetes } \\
\text { self-efficacy, and diabetes } \\
\text { self management on } \\
\text { glycemic control among } \\
\text { Chinese population with } \\
\text { type } 2 \text { diabetes mellitus }\end{array}$ & 2017 & $\begin{array}{lr}\text { Laurie } & \text { Quinn, } \\
\text { Keke r Lin, } \\
\text { Chang Park, } \\
\text { Mingzi ri, } \\
\text { Xiudong Wang, } \\
\text { Xiushu Li, Wei } \\
\text { Li }\end{array}$ & $\begin{array}{l}\text { Cross- } \\
\text { sectional }\end{array}$ & $\begin{array}{l}\text { Usia } \\
\text { dewasa } \\
(\geq 18 \\
\text { tahun) }\end{array}$ & $\begin{array}{l}\text { Depresi dan stress diabetes hanya } \\
\text { memiliki efek tidak langsung pada } \\
\text { kontrol glikemik melalui efikasi diri } \\
\text { diabetes dan diabetes self } \\
\text { management. }\end{array}$ \\
\hline $\begin{array}{l}\text { Importance of } \\
\text { family/social support and } \\
\text { impact on adherence to } \\
\text { diabetic therapy }\end{array}$ & 2013 & $\begin{array}{l}\text { T. Miller \& M. } \\
\text { Dimatteo }\end{array}$ & $\begin{array}{l}\text { Cross- } \\
\text { sectional }\end{array}$ & $\begin{array}{l}\text { Usia } \\
\text { dewasa } \\
(\geq 18 \\
\text { tahun })\end{array}$ & $\begin{array}{l}\text { Dukungan keluarga dan sosial } \\
\text { merupakan aspek penting dari } \\
\text { kepatuhan terhadap manajemen } \\
\text { diabetes. Sejumlah studi } \\
\text { korelasional telah menunjukkan } \\
\text { hubungan yang positif dan } \\
\text { signifikan antara dukungan sosial } \\
\text { dan kepatuhan terhadap } \\
\text { pengobatan diabetes. }\end{array}$ \\
\hline
\end{tabular}

\begin{tabular}{|c|c|c|c|c|c|}
\hline $\begin{array}{l}\text { Social support and self- } \\
\text { management capabilities } \\
\text { in diabetes patients: An } \\
\text { international } \\
\text { Observational study }\end{array}$ & 2016 & $\begin{array}{l}\text { Jan } \\
\text { Koetsenruijter, } \\
\text { et. al }\end{array}$ & $\begin{array}{l}\text { Cross- } \\
\text { sectional }\end{array}$ & $\begin{array}{l}\text { Usia } \\
\text { dewasa } \\
(\geq 18 \\
\text { tahun })\end{array}$ & $\begin{array}{l}\text { Beberapa karakteristik jejaring } \\
\text { sosial menunjukkan hubungan } \\
\text { positif dengan kapabilitas self- } \\
\text { management. Pengaruh dukungan } \\
\text { informasional terkuat pada } \\
\text { populasi pendidikan rendah. }\end{array}$ \\
\hline
\end{tabular}

\begin{tabular}{|c|c|c|c|c|}
\hline $\begin{array}{l}\text { The relationship between } \\
\text { depressive symptoms, } \\
\text { diabetes symptoms, and } \\
\text { self-management among } \\
\text { an urban, low-income }\end{array}$ & 2015 & $\begin{array}{l}\text { Annie L. } \\
\text { Nguyen, } \\
\text { Janelle Green, } \\
\text { Susan } \\
\text { Enguidanos }\end{array}$ & $\begin{array}{l}\text { Cross- } \\
\text { sectional }\end{array}$ & $\begin{array}{l}\text { Usia } \\
\text { dewasa } \\
(\geq 40 \\
\text { tahun) }\end{array}$ \\
\hline
\end{tabular}

$31,5 \%$ dari peserta menunjukkan

kemungkinan depresi berat.

Memiliki gejala depresi merupakan

indikator gejala diabetes yang lebih buruk. Skrining untuk gejala depresi dapat membantu mengidentifikasi individu yang membutuhkan dukungan tambahan dengan gejala diabetes dan manajemen diri.

\begin{tabular}{|c|c|c|c|c|c|}
\hline $\begin{array}{l}\text { Social support and coping } \\
\text { in adults with type } 2 \\
\text { diabetes }\end{array}$ & 2017 & $\begin{array}{l}\text { Samantha } \\
\text { Ramkisson, } \\
\text { Basil J. Pillay, } \\
\text { Wilbert } \\
\text { Sibanda }\end{array}$ & $\begin{array}{l}\text { Cross- } \\
\text { sectional }\end{array}$ & $\begin{array}{l}\text { Usia } \\
\text { dewasa } \\
(\geq 18 \\
\text { tahun })\end{array}$ & $\begin{array}{l}\text { Hasil penelitian menunjukkan } \\
\text { bahwa terdapat hubungan terbalik } \\
\text { antara dukungan sosial dan koping, } \\
\text { yang menunjukkan bahwa } \\
\text { peningkatan dukungan sosial }\end{array}$ \\
\hline
\end{tabular}

Dwitanta, S., \& Dahlia, D.,_Diabetes Self Management dan Faktor yang Mempengaruhinya... 26 
Jurnal Ilmu Keperawatan Medikal Bedah Vol. 3 (2), Bulan November Tahun 2020 , Hal. 23-31 ISSN 2338-2058 (print), ISSN 2621-2986 (online)

\begin{tabular}{|c|c|c|c|c|c|}
\hline Judul & Tahun & Penulis & Metode & Sampel & Hasil \\
\hline & & & & & $\begin{array}{l}\text { dikaitkan dengan penurunan } \\
\text { tekanan emosional. }\end{array}$ \\
\hline $\begin{array}{l}\text { Relationship between } \\
\text { self-efficacy, self-care } \\
\text { behaviour and glycaemic } \\
\text { control among patients } \\
\text { with type } 2 \text { diabetes } \\
\text { mellitus in the Malaysian } \\
\text { primary care setting }\end{array}$ & 2019 & $\begin{array}{l}\text { Z. Tharek, A. S. } \\
\text { Ramli, D. L. } \\
\text { Whitford et al. }\end{array}$ & $\begin{array}{l}\text { Cross- } \\
\text { sectional }\end{array}$ & $\begin{array}{l}\text { Usia } \\
\text { dewasa } \\
(\geq 18 \\
\text { tahun) }\end{array}$ & $\begin{array}{l}\text { Hasil menunjukkan bahwa efikasi } \\
\text { diri yang lebih tinggi berhubungan } \\
\text { dengan perilaku perawatan diri } \\
\text { yang baik dan kontrol glikemik } \\
\text { yang lebih baik. Temuan dari } \\
\text { penelitian ini menunjukkan } \\
\text { pentingnya memasukkan kegiatan } \\
\text { efikasi diri dalam pengelolaan } \\
\text { diabetes mellitus tipe } 2 \text { di } \\
\text { perawatan primer. }\end{array}$ \\
\hline
\end{tabular}

\begin{tabular}{|c|c|c|c|c|c|}
\hline $\begin{array}{l}\text { An assessment of self- } \\
\text { care knowledge among } \\
\text { patients with diabetes } \\
\text { mellitus. }\end{array}$ & 2019 & $\begin{array}{l}\text { Alhaik, S, } \\
\text { Anshasi, H. A., } \\
\text { Alkhawaldeh, J. } \\
\text { f., Soh, K. L., \& } \\
\text { Naji, A. M. }\end{array}$ & $\begin{array}{l}\text { Cross- } \\
\text { sectional }\end{array}$ & $\begin{array}{l}\text { Usia } \\
\text { dewasa } \\
(\geq 18 \\
\text { tahun })\end{array}$ & $\begin{array}{l}\text { Penelitian ini menekankan bahwa } \\
\text { pasien diabetes memiliki tingkat } \\
\text { pengetahuan cukup dan ada banyak } \\
\text { kebutuhan pembelajaran. Tenaga } \\
\text { kesehatan memiliki peran penting } \\
\text { dalam mengembangkan program } \\
\text { pendidikan diabetes yang sesuai } \\
\text { berdasarkan kebutuhan belajar } \\
\text { pasien dan karakteristik nasien. }\end{array}$ \\
\hline
\end{tabular}

\section{PEMBAHASAN}

Pasien usia dewasa pertengahan yang memiliki diabetes mempunyai risiko lebih tinggi terjadinya komplikasi serta berpeluang untuk mengalami kondisi komorbiditas (CKD, retinopati dan neuropati) dan risiko perburukan kondisi penyakit (seperti kerusakan organ tahap akhir) yang erat kaitannya dengan buruknya kontrol gula darah (Beverly et al., 2016; Li et al., 2017; Weinger et al., 2014). Pasien usia dewasa pertengahan yang menderita diabetes melitus menunjukan tingkat self-care yang rendah dalam mengelola gejala dan kesulitan dalam mematuhi perilaku self-care dalam jangka panjang (Kim \& Lee, 2019). Hal ini dapat dibuktikan dari penelitian Pantalone et al. (2018) menjelaskan dari total 32.174 responden ditemukan sebanyak 9.983 (31\%) responden usia antara 47 - 64 tahun memiliki kontrol gula darah yang buruk $(\mathrm{HbA} 1 \mathrm{c} \geq 64 \mathrm{mmol} / \mathrm{mol})$ disertai dengan bermacam-macam komplikasi. Hal tersebut dapat terjadi akibat adanya kontrol glikemik yang buruk serta pengelolaan diabetes yang tidak tepat. Penelitian lain juga menjelaskan bahwa ada beberapa faktor yang dapat memicu terjadinya kontrol glikemik yang buruk yaitu seperti kepatuhan pasien yang buruk terhadap rencana perawatan dan pelaksanaan manajemen diabetes yang sudah di tentukan, sikap buruk dari pasien (seperti kurangnya motivasi dalam menjaga kesehatan mereka sendiri, dengan ketergantungan pada penyedia pelayanan kesehatan), kurang atau terbatasnya pengetahuan pasien (khususnya tentang diabetes, komplikasi dan tujuan pengobatannya), adanya pengaruh budaya (transkultural) dan keyakinan pasien dengan pengobatan tradisional diabetes serta kurangnya dukungan dari keluarga (Romakin \& Mohammadnezhad, 2019).

Dwitanta, S., \& Dahlia, D.,_Diabetes Self Management dan Faktor yang Mempengaruhinya... 27 
Jurnal Ilmu Keperawatan Medikal Bedah Vol. 3 (2), Bulan November Tahun 2020 , Hal. 23-31 ISSN 2338-2058 (print), ISSN 2621-2986 (online)

Studi lain menjelaskan juga bahwa depresi dapat memberikan pengaruh terhadap individu dalam melakukan kemampuan manajemen diri yang berpengaruh pada penurunan kualitas hidup seseorang. Hasil penelitian Schinckus, Dangoisse, Broucke, and Mikolajczak (2018) yang meneliti tentang apakah tekanan emosional atau depresi memoderasi hubungan antara sadar akan kesehatan, efikasi diri dan perilaku perawatan diri diabetes. Hasil pada penelitian ini didapatkan menegaskan bahwa sadar akan kesehatan dan kemandirian diri secara signifikan memprediksi perilaku perawatan diri $(\mathrm{p}<.001)$. Sebaliknya, tekanan dan depresi tidak memoderasi pengaruh self-efficacy pada perilaku perawatan-diri diabetes. Karena pengobatan diabetes memerlukan aktivitas perawatan diri yang luas, kapasitas pasien untuk mengelola penyakitnya sendiri adalah penentu utama hasil pengobatan. Kapasitas perilaku ini dapat dipengaruhi oleh faktor kognitif dan afektif. Namun, untuk sadar akan kesehatan memberikan efek yang positif untuk menghilang ketika pasien mengalami depresi atau tekanan terkait diabetes. Hasil pada penelitian ini memberikan bukti baru tentang peran faktor kognitif dan emosional dalam manajemen diri diabetes.

Penelitian yang dilakukan oleh Lin et al. (2017) menjelaskan bahwasanya depresi, stres diabetes, dan efikasi diri diabetes mempengaruhi tingkat kontrol glikemik secara tidak langsung melalui manajemen diri diabetes. Hal tersebut dapat terjadi dikarenakan hanya sebanyak 91 (35,82\%) responden mencapai kontrol glikemik optimal dengan kadar HbA1c $<7,0 \%$ (53 mmol / mol). Manajemen mandiri diabetes yang memiliki efek langsung pada kontrol glikemik (OR $=0,95, \mathrm{P}<0,001)$. Depresi dan stres diabetes hanya memiliki efek tidak langsung pada kontrol glikemik melalui efikasi diri diabetes dan manajemen diri diabetes. Kemandirian diabetes hanya memiliki efek tidak langsung pada kontrol glikemik melalui manajemen diri diabetes (Nguyen, Green, \& Enguidanos, 2015).

Selain depresi ada pula faktor lain yang dapat mempengaruhi diabetes self management yaitu dukungan sosial. Dukungan sosial merupakan informasi yang diberikan dari orang lain termasuk menyayangi dan menjaga, bernilai dan berharga serta merupakan bagian dari jaringan komunikasi (Mondesir, White, Liese, \& McLain, 2016). Dukungan sosial dapat berupa dukungan fungsional yaitu meliputi kebiasaan yang dapat memberikan dukungan emosional. Penelitian Miller and Dimatteo (2013) menunjukkan ada hubungan yang positif dan signifikan antara dukungan sosial dan kepatuhan pengobatan di antara pasien dengan diabetes. Dukungan sosial dari keluarga dapat memberikan bantuan praktis dan dapat membantu menahan tekanan hidup pasien dengan penyakit diabetes.

Hal tersebut berkebalikan dengan penelitian Ramkisson, Pillay, and Sibanda (2017) tentang dukungan sosial yaitu didapatkan temuan menunjukkan bahwa ada hubungan terbalik antara dukungan sosial dan koping, yang menunjukkan bahwa peningkatan dukungan sosial dikaitkan dengan penurunan tekanan emosional. Ada korelasi positif kecil antara SSQ dan WHO-5, yang menunjukkan responden yang memiliki dukungan sosial yang baik mendukung tingkat kesejahteraan yang lebih baik. Ini sesuai dengan literatur yang menunjukkan bahwa dukungan keluarga memainkan peran penting dalam pengelolaan diabetes dan dapat membantu untuk perilaku perawatan diri pasien (Amelia, Wahyuni, \& Felicia, 2018). Menurut Ramkisson et al. (2017) menjelaskan keluarga adalah konteks

Dwitanta, S., \& Dahlia, D.,_Diabetes Self Management dan Faktor yang Mempengaruhinya... 28 
Jurnal Ilmu Keperawatan Medikal Bedah Vol. 3 (2), Bulan November Tahun 2020 , Hal. 23-31 ISSN 2338-2058 (print), ISSN 2621-2986 (online)

terpenting di mana penyakit dapat diatasi; oleh karena itu, dukungan sosial dari keluarga dapat membantu dalam hasil pengobatan untuk pasien. Karena itu, penting untuk memasukkan keluarga sebagai bagian dari regiment perawatan pasien.

Hal lain juga yang mempengaruhi pelaksanaan diabetes self managment yaitu faktor pengetahuan. Pengetahuan merupakan bagian yang penting dalam terbentuknya tindakan seseorang yang berasal dari panca indra. Berdasarkan hasil pengalaman didapatkan hasil bahwa perilaku yang berlandaskan pengetahuan akan lebih cepat bertindak daripada yang tidak cukup pengetahuan. Alhaik et al. (2019) menjelaskan dalam penelitiannya bahwa tingkat keseluruhan pengetahuan perawatan diri diabetes pada semua sampel penelitian adalah pada pengetahuan sedang (58,28\%). Tingkat pengetahuan tertinggi pada bagian perencanaan makan $(70,2 \%)$ dan untuk pengetahuan tingkat terendah adalah bagian olahraga $(42,5 \%)$. Selain itu, pengetahuan perawatan diri diabetes ditemukan ada hubungan dengan usia, status pendidikan, obat-obatan diabetes dan lamanya sakit. Hasil temuan pada penelitian ini menekankan bahwa pasien diabetes memiliki rata-rata tingkat pengetahuan sedang. Hal tersebut didukung oleh pernyataan Wawan and Dewi (2010) yang mengungkapkan dalam teorinya bahwa pengetahuan dapat dipengaruhi oleh beberapa faktor yaitu faktor internal dan faktor eksternal. Faktor internal diantara lain tingkat pendidikan, pekerjaan dan usia. Sedangkan untuk faktor eksternal yaitu faktor lingkungan dan sosial budaya.

Adanya faktor lain yang berperan penting dalam mempengaruhi pelaksanaan diabetes self management yaitu efikasi diri. Efikasi diri adalah keyakinan yang digambarkan sebagai kepercayaan diri atau keyakinan tentang kemampuan diri sendiri, ataupun merupakan keyakinan individu bahwa dia mampu menguasai atau mengontrol segala situasi atau kondisi serta mempu menghasilkan hal yang lebih positif. Efikasi adalah bentuk dari penilaian diri, apakah seseorang mampu melakukan tindakan yang baik atau buruk, tepat atau salah, bisa atau tidak bisa mengerjakan sesuatu yang dipersyaratkan (Priyoto, 2014). Tharek et al. (2018) menyebutkan bahwa efikasi diri terdapat hubungan yang positif terhadap perilaku perawatan diri. Nilai efikasi diri terbukti mampu dalam membantu menurunan nilai HbA1c. Hal tersebut menunjukan bahwa efikasi diri yang tinggi sangat berkaitan dengan peningkatan perilaku perawatan diri dan terkontrolnya glikemik yang lebih baik. Dalam penelitian lain menunjukan bahwa adanya peran efikasi diri mampu memberikan kerangka kerja yang cocok dalam memahami dan memperkirakan komitment seseorang terhadap perilaku perawatan diri dan efektifitas manajemen diri diabetes (Mohebi, Azadbakht, Feizi, Sharifirad, \& Kargar, 2013).

\section{SIMPULAN}

Peneliti dapat menarik hipotesis sementara bahwa dari keempat faktor tersebut terdapat hubungan yang erat dan saling berkaitan dalam mempengaruhi pelaksanaan diabetes self managmenet pada usia dewasa pertengahan dengan diabetes melitus tipe 2. Faktor tersebut berupa variabel depresi, efikasi diri, dukungan sosial dan pengetahuan. Faktor-faktor tersebut sangat mengganggu pasien dengan diabetes melitus dalam mengontrol gula darah,

Dwitanta, S., \& Dahlia, D.,_ Diabetes Self Management dan Faktor yang Mempengaruhinya... 29 
Jurnal Ilmu Keperawatan Medikal Bedah Vol. 3 (2), Bulan November Tahun 2020 , Hal. 23-31 ISSN 2338-2058 (print), ISSN 2621-2986 (online)

sehingga diperlukannya peran perawat dalam mengatasi hal tersebut agar permasalahan dalam melakukan diabetes self management yang dilakukan oleh pasien diabetes melitus tidak terganggu dan target kontrol glikemik tercapai. Maka dari itu, penting adanya penelitian lebih lajut untuk dapat melihat faktor mana yang paling berpengaruh diantara keempat tersebut, sehingga perawat dapat mempersiapkan strategi yang akan dilakukan perawat dalam mengatasi permasalahan tersebut.

\section{REFERENSI}

Alhaik, S., Anshasi, H. A., Alkhawaldeh, J. f., Soh, K. L., \& Naji, A. M. (2019). An assessment of self-care knowledge among patients with diabetes mellitus. Diabetes \& Metabolic Syndrome: Clinical Research \& Reviews, 13(1), 390-394. doi:10.1016/j.dsx.2018.10.010

Amelia, R., Wahyuni, A., \& Felicia, R. A. (2018). Relationship between family support with quality of life among type 2 diabetes mellitus patients at Amplas primary health care in Medan, Indonesia. Paper presented at the Journal of Physics: Conference Series.

Arambewela, M. H., Somasundaram, N. P., Jayasekara, H. B. P. R., Kumbukage, M. P., Jayasena, P. M. S., Chandrasekara, C. M. P. H., . . Kusumsiri, D. P. (2018). Prevalence of Chronic Complications, Their Risk Factors, and the Cardiovascular Risk Factors among Patients with Type 2 Diabetes Attending the Diabetic Clinic at a Tertiary Care Hospital in Sri Lanka. journal of Diabetes Research, 2018 doi:https://doi.org/10.1155/2018/4504287

Beverly, E. A., Ritholz, M. D., Shepherd, C., \& Weinger, K. (2016). The Psychosocial Challenges and Care of Older Adults with Diabetes: "Can't Do What I Used To Do; Can't Be Who I Once Was". Curr Diab Rep, 16(6), 48. doi:10.1007/s11892-016-0741-7

IDF. (2019). Diabetes Atlas 9th edition 2019. In Diabetes Atlas 9th edition 2019: International Diabetes Federation.

Kim, M. Y., \& Lee, E. J. (2019). Factors Affecting Self-Care Behavior Levels among Elderly Patients with Type 2 Diabetes: A Quantile Regression Approach. Medicina (Kaunas), 55(7). doi:10.3390/medicina55070340

Kirk, J. K., Arcury, T. A., Ip, E., Bell, R. A., Saldana, S., Nguyen, H. T., \& Quandt, S. A. (2015). Diabetes symptoms and self-management behaviors in rural older adults. Diabetes Res Clin Pract, 107(1), 54-60. doi:10.1016/j.diabres.2014.10.005

Li, C. L., Chiu, Y. C., Bai, Y. B., Lin, J. D., Stanaway, F., \& Chang, H. Y. (2017). The co-occurrence of depressive symptoms and cognitive impairment and its relationship with self-care behaviors among community dwelling older adults with diabetes. Diabetes Res Clin Pract, 129, 73-78. doi:10.1016/j.diabres.2017.03.025

Lin, K., Park, C., Li, M., Wang, X., Li, X., Li, W., \& Quinn, L. (2017). Effects of depression, diabetes distress, diabetes self-efficacy, and diabetes self management on glycemic control among Chinese population with type 2 diabetes mellitus. Diabetes Research and Clinical Practice, 131, 179-186. Retrieved from http://www.sciencedirect.com/science/article/pii/S0168822716308191. doi:https://doi.org/10.1016/j.diabres.2017.03.013

Miller, T., \& Dimatteo, M. (2013). Importance of family/social support and impact on adherence to diabetic therapy. Diabetes, metabolic syndrome and obesity : targets and therapy, 6, 421-426. doi:10.2147/DMSO.S36368

Dwitanta, S., \& Dahlia, D.,_Diabetes Self Management dan Faktor yang Mempengaruhinya... 30 
Jurnal Ilmu Keperawatan Medikal Bedah Vol. 3 (2), Bulan November Tahun 2020 , Hal. 23-31 ISSN 2338-2058 (print), ISSN 2621-2986 (online)

Mohebi, S., Azadbakht, L., Feizi, A., Sharifirad, G., \& Kargar, M. (2013). Review the key role of self-efficacy in diabetes care. J Educ Health Promot, 2, 36. doi:10.4103/22779531.115827

Mondesir, F. L., White, K., Liese, A. D., \& McLain, A. C. (2016). Gender, Illness-Related Diabetes Social Support, and Glycemic Control Among Middle-Aged and Older Adults. J Gerontol B Psychol Sci Soc Sci, 71(6), 1081-1088. doi:10.1093/geronb/gbv061

Ncube, N. (2019). The Impact of Diabetes Mellitus II on Longevity and Morbidity Risk.

Nguyen, A. L., Green, J., \& Enguidanos, S. (2015). The relationship between depressive symptoms, diabetes symptoms, and self-management among an urban, low-income Latino population. Journal of Diabetes and its Complications, 29(8), 1003-1008. Retrieved http://www.sciencedirect.com/science/article/pii/S1056872715003748. doi:https://doi.org/10.1016/j.jdiacomp.2015.09.004

Pantalone, K. M., Misra-Hebert, A. D., Hobbs, T. M., Wells, B. J., Kong, S. X., Chagin, K., ... Kattan, M. W. (2018). Effect of glycemic control on the Diabetes Complications Severity Index score and development of complications in people with newly diagnosed type 2 diabetes. Journal of Diabetes, 10(3), 192-199. doi:10.1111/1753-0407.12613

Priyoto. (2014). Teori Sikap \& Perilaku dalam Kesehatan. Yogyakarta: Nuha medika.

Ramkisson, S., Pillay, B. J., \& Sibanda, W. (2017). Social support and coping in adults with type 2 diabetes. Afr J Prim Health Care Fam Med, 9(1), e1-e8. doi:10.4102/phcfm.v9i1.1405

Riskesdas. (2018). Riset Kesehatan Dasar. Retrieved from Jakarta: http://www.depkes.go.id/resources/download/infoterkini/materi rakorpop 2018/Hasil\%20Riskesdas\%202018.pdf

Romakin, P., \& Mohammadnezhad, M. (2019). Patient-related factors associated with poor glycaemic control among patients with type 2 diabetes mellitus. Australian journal of general practice, 48(8), 557-563. doi:10.31128/AJGP-02-19-4859

Schinckus, L., Dangoisse, F., Broucke, S. V. d., \& Mikolajczak, M. (2018). When knowing is not enough: Emotional distress and depression reduce the positive effects of health literacy on diabetes self management. Patient Education and Counseling, 101(2), 324-330. Retrieved http://www.sciencedirect.com/science/article/pii/S0738399117304809. doi:https://doi.org/10.1016/j.pec.2017.08.006

Tharek, Z., Ramli, A. S., Whitford, D. L., Ismail, Z., Mohd Zulkifli, M., Ahmad Sharoni, S. K., ... Jayaraman, T. (2018). Relationship between self-efficacy, self-care behaviour and glycaemic control among patients with type 2 diabetes mellitus in the Malaysian primary care setting. BMC Fam Pract, 19(1), 39. doi:10.1186/s12875-018-0725-6

Wawan, A., \& Dewi, M. (2010). Teori dan pengukuran pengetahuan, sikap dan perilaku manusia. Yogyakarta: Nuha Medika, 11-18.

Weinger, K., Beverly, E. A., \& Smaldone, A. (2014). Diabetes self-care and the older adult. West J Nurs Res, 36(9), 1272-1298. doi:10.1177/0193945914521696

Widodo, F. Y. (2014). Pemantauan penderita diabetes mellitus. Ilmiah Kedokteran, 3(2), 55-69. Wu, F. L., Tai, H. C., \& Sun, J. C. (2019). Self-management Experience of Middle-aged and Older Adults With Type 2 Diabetes: A Qualitative Study. Asian Nurs Res (Korean Soc Nurs Sci), 13(3), 209-215. doi:10.1016/j.anr.2019.06.002

Dwitanta, S., \& Dahlia, D.,_Diabetes Self Management dan Faktor yang Mempengaruhinya... 31 